\title{
Anti-Aging Activities of Asparagus Gel Ethanol Extract in Cosmetic Gel Agent for Facial Skin
}

\author{
Henny Safrita Ginting, ${ }^{1}$ Edy Fachrial, ${ }^{2}$ I Nyoman Ehrich Lister, ${ }^{2}$ Adek Amansyah ${ }^{2}$ \\ ${ }^{1}$ Master Program of Biomedical Sciences, Universitas Prima Indonesia, Medan, Indonesia, \\ ${ }^{2}$ Faculty of Medicine, Universitas Prima Indonesia, Medan, Indonesia
}

\begin{abstract}
Asparagus is a vegetable that contains phenolic compounds with antioxidant properties that scavenges agingtriggering free radicals. This study aimed to investigate the components and anti-aging potentials of Ethanol Extract form Asparagus (EEA). The study was performed in February 2020 at the Pharmacy Laboratory, University of North Sumatera. The EEA was obtained through maceration using $96 \%$ ethanol. An antioxidant assay was performed and the total phenol and flavodoid content were determined using the spectroscopic method. Three gel formulas with different concentrations of EEA was prepared (F1: 1.5\%, F2: 2.5\%, and F3: 3.5\%), and F0 was used as control. The parameters evaluated were moisture, oil content, texture, collagen, wrinkle, pigment, sensitivity, and pore. The result showed that asparagus had a moderate antioxidant activity (IC50: 118,992) with the total phenol and flavonoid contents of 15,9407 $\mathrm{mg} \mathrm{GAE} / \mathrm{g}$ and 3,2286 $\mathrm{mg} \mathrm{QE} / \mathrm{g}$ extract, respectively. The highest aging activities was seen in F3 (3.5\%), followed by F2 (2.5\%) and F1 (1.5\%). The percentage of moisture, oil, texture, collagen, wrinkle, spot, sensitivity, and pore recovery were found to be $40.15 \%, 49.73 \%, 71.76 \%$, $17.70 \%, 70.93 \%, 49.34 \%, 42.56 \%$ and $25.31 \%$, respectively. Hence, it can be concluded that the EEA Gel at the highest concentration (3.5\%) has a high content of phenol and flavonoid which can improve the skin moisture, oil content, texture, collagen, wrinkles, spots, sensitivity, and pores, which promotes anti-aging activities.
\end{abstract}

Key words: Anti-aging, antioxidant, asparagus

\section{Pengaruh Ekstrak Etanol Asparagus sebagai Sediaan Kosmetik Gel Anti-Penuaan Terhadap Kulit Wajah}

\begin{abstract}
Abstrak
Asparagus adalah sayuran yang mengandung senyawa fenol dengan kemampuan sebagai antioksidan. Antioksidan dapat menangkal radikal bebas penyebab penuaan. Penelitian ini bertujuan mengetahui kandungan antioksidan dan potensi efek anti-aging pada EEA. Penelitian dilakukan pada bulan Februari 2020 di Laboratorium Farmasi Universitas Sumatera Utara. Sementara itu, ekstrak diperoleh secara maserasi menggunkaan etanol 96\%. Pengujian antioksidan dan penetapan kadar total fenol dan flavonoid dilakukan dengan metode spektroskopi. Tiga formula gel dengan konsentrasi EEA yang berbeda disiapkan (F1: 1,5\%, F2: 2,5\%, dan F3: 3,5\%), dan F0 digunakan sebagai kontrol. Parameter uji berupa kadar air, kadar minyak, tekstur, kolagen, keriput, pigmen, sensitivitas, dan pori. Hasil penelitian menunjukkan bahwa asparagus memiliki aktivitas antioksidan sedang (IC : $_{50}$ 118,992) dengan kandungan total fenol dan flavonoid masing-masing sebesar 15,9407 mg GAE/g dan 3,2286 mg QE/g ekstrak. Aktivitas penuaan tertinggi terlihat pada F3 (3,5\%), diikuti oleh F2 (2,5\%) dan F1 (1,5\%). Persentase kelembaban, minyak, tekstur, kolagen, kerutan, flek, sensitivitas, dan pemulihan pori ditemukan tiaptiap 40,15\%, 49,73\%, 71,76\%, 17,70\%, 70,93\%, 49,34\%, 42,56\% dan 25,31\%. Simpulan, gel EEA pada konsentrasi tertinggi $(3,5 \%)$ memiliki kandungan fenol dan flavonoid yang tinggi yang dapat memperbaiki kelembaban kulit, kandungan minyak, tekstur, kolagen, kerutan, flek, sensitivitas, dan pori-pori, yang menjanjikan aktivitas antipenuaan.
\end{abstract}

Kata kunci: Anti penuaan, antioksidan, asparagus

Corresponding Author: Henny Safrita Ginting, Master Program of Biomedical Sciences, Universitas Prima Indonesia, Medan, Indonesia, Email: yysunpri@gmail.com 


\section{Introduction}

Aging is a natural process that cannot be avoided by all living beings, including human. Aging is due to the anatomical, as well as physiological, damages in the body, which occurs in all organs including in blood vessels and skin. The extrinsic aging of the skin, or referred to as photoaging, is mainly affected by the ultraviolet (UV) rays, with the exposure to UV radiation from sunlight as the biggest contributing factor, of premature aging symptoms, contributing up to $90 \%$. The thinning of skin layers triggered by the sun exposure and clumping of pigments (melanocyte cells) causes spots and dry skin. ${ }^{1}$ Photoaging triggers $80 \%$ of skin aging problems through the stimulation of free radicals, as well as activating cytokines and metalloprotein collagenases. Thus, collagen and elastin (ELN) form cross-links in the skin, leading to the loss of elasticity, thinning the epidermal layer, and creating wrinkles. ${ }^{2}$ Collagen is also the most abundant component of the dermis that contributes around $70 \%$ of the skin dry mass; hence, its damage will become the major cause of wrinkling, loss of elasticity, and sagging.

There are two main regulators of fibroblastrelated collagen formation: transforming growth factor (TGF- $\beta$ ) and activator protein (AP-1). TGF- $\beta$ is a cytokine that stimulates the collagen production, while AP-1 is a transcription factor that inhibits collagen production and stimulates collagen breakdown. The intrinsic aging plays a role in decreasing TGF- $\beta$ and accumulation of Reactive oxygen species (ROS), while the extrinsic aging, mainly caused by UV radiation (photoaging), increases ROS production in the dermis layer. Furthermore, ROS triggers a series of chain molecular reactions, thereby increasing the formation of AP-1, which then stimulates the transcription process of Matrix metallopeptidase (MMP) enzyme in collagen degradation and also inhibits collagen synthesis by inhibiting the type 2 receptors of TGF- $\beta .^{3}$

Antioxidants can prevent aging by playing the role of antidote to free radicals from photoaging by working synergistically to protect cells, as well as organ systems, from damage. Asparagus contains phenolic compounds with antioxidant properties that cleanse toxic and acne-triggering substances produced by photoaging on the face. $e^{4,5}$ The benefits of natural ingredients have been identified for managing various dermatological disorders and these ingredients have also been used traditionally over the last 20 years. An active natural ingredient can be formulated into cosmetics that can be used safely and has lower side effects when compared to synthetic cosmetics. ${ }^{6}$ The category of cosmetic preparation usually made of these ingredients is gel, which is non-sticky, easy to wash, leaves no oil on the skin, and has stable viscosity during storage. Skincare for aging is best to be introduced at the earliest opportunity for healthy and wellmaintained skin, especially the facial skin. ${ }^{7}$ Total phenolic and total flavonoids are shown to be positively correlated with antioxidant activities. ${ }^{8}$ This study aimed to investigate the antioxidant activity, total phenolic, and flavonoid content of the ethanol extract of Asparagus (EEA) and its anti-aging potential.

\section{Methods}

This study was performed in February 2020 at the Pharmacy Laboratory, University of North Sumatera. This study evaluated the antioxidant activity of the EEA by DPPH (2,2-diphenyl-1picrylhydrazyl) and total phenolic and flavonoid content through the use of Folin-Ciocalteau and Aluminum chloride.

Furthermore, the EEA was formulated into a gel form ( $\mathrm{F} 0=\mathrm{Gel}$ Base, $\mathrm{F} 1=\mathrm{Gel}$ of $1.5 \%$ EEA, $\mathrm{F} 2=\mathrm{Gel}$ of $2.5 \% \mathrm{EEA}$, and $\mathrm{F} 3=\mathrm{Gel}$ of $3.5 \%$ EEA) and the efficacy of the gel was evaluated by 12 volunteers who have been informed about the purpose and procedure of the study in a doubleblind clinical trial. The volunteers were selected according to the inclusion and exclusion criteria. The inclusion criteria was healthy women or men in productive age (20-25 years) with no history of allergy-related illnesses, who were willing to receive treatment using gel for 4 weeks, twice daily (day and night), while the exclusion criteria were irritation of the gel, history of an allergy-related illness, and in the care of another dermatologist. Parameters evaluated in this study were moisture, oil content, texture, collagen, wrinkle, pigment, sensitivity, and pores, which were evaluated every week for a month. This clinical trial procedure has been approved by the Health Research Ethics Commission of Universitas Prima Indonesia with the issuance of Letter No. 022/KEPK/UNPRI/I/2020.

The preparation of EEA was begun by washing and drying the asparagus at room temperature. The dried simplicia was then blended into its powder form and extracted. The extraction was performed by maceration using $96 \%$ ethanol for 7 days at room temperature. The filtrate from the maceration evaporated by a rotary evaporator and obtained a concentrated form of EEA. ${ }^{9}$ 
The obtained EEA subsequently underwent a phytochemical screening with the Indonesian Herbal Pharmacopeia as the reference. In this stage, these phytochemicals was screened by some reagents, inclusing dragendorf, $\mathrm{Mayer}, \mathrm{ICl}_{3}$ for flavonoids, bouchardat for alkaloids, $\mathrm{A} \mathrm{FeCl}_{3}$ for tannins, Lieberman Burchard for steroids or triterpenoids, sulfuric acid for saponins, Shinoda test (magnesium, concentrated chloride acid, amyl alcohol), and glycoside test with glacial acetic acid, ferric chloride, sulphuric acid ${ }^{10}$

DPPH scavenging assay was then performed against EEA. DPPH solution of $2 \mathrm{~mL}(200 \mu \mathrm{g} / \mathrm{mL}$ in methanol) was mixed with $0 \mathrm{~mL}, 0.4 \mathrm{~mL}, 0.8$ $\mathrm{mL}, 1.2 \mathrm{~mL}$ and $2 \mathrm{~mL}$ of EEA ( $500 \mu \mathrm{g} / \mathrm{mL})$ to form concentrations of $0,60,70,80$, and $90 \mu \mathrm{g} / \mathrm{mL}$, respectively. The comparison used was vitamin $C$ with a concentration of $2,4,6$, and $8 \mu \mathrm{g} / \mathrm{mL}$. Each solution was vortexed and incubated in the dark at room temperature for 30 minutes, and the absorbance was measured at a wavelength of $516 \mathrm{~nm}$ against the blank. Then, the DPPH radical inhibition of sample (\%) was calculated by dividing the difference between the blank absorbance and sample absorbance. ${ }^{11}$ The percentage of free radical scavenging activity obtained was then plotted by linear regression model for $\mathrm{IC}_{50}$ of DPPH.

The calculation of the total phenol content was carried out using the gallic acid standard, and the calibration curve used a concentration of $0,31,25,62,5,125$, and $250 \mu \mathrm{g} / \mathrm{mL}$ gallic acid. The ethanol extract of asparagus was prepared in a concentration of $1000 \mathrm{ppm}$, and $0.1 \mathrm{~mL}$ of each solution was mixed with $7.9 \mathrm{~mL}$ of distilled water and $0.5 \mathrm{~mL}$ of Folin-Ciocalteau and was vortexed for \pm 1 minute. Furthermore, $1.5 \mathrm{~mL}$ of $20 \% \mathrm{Na}_{2} \mathrm{CO}_{3}$ was added to the solution and incubated for 90 minutes. The absorbance was measured at a wavelength of $775 \mathrm{~nm} .{ }^{1}$ Meanwhile, total flavonoid content was measured using the quercetin standard with a concentration of 0,6 , $14.5,19$, and $23.5 \mu \mathrm{g} / \mathrm{mL}$. The ethanol extract of asparagus was prepared in a concentration of $1000 \mathrm{ppm}$, and $2 \mathrm{~mL}$ of each solution was mixed with $0.1 \mathrm{~mL}$ of $\mathrm{AlCl}_{3}, 0.1 \mathrm{~mL} \mathrm{CH}_{3} \mathrm{COONa}$, and 2.8 $\mathrm{mL}$ distilled water and incubated for 40 minutes. The absorbance was measured at a wavelength of $440 \mathrm{~nm} \cdot{ }^{1,12}$ The total phenolic content and total flavonoid content were determined by multiple concentration $(\mu / \mathrm{mL})$, volumes and the dilution factors, which was then divided against the mass of the sample.

On the other hand, the obtained EEA was also formulated as a gel, and the base formulation followed the standard formulation, as shown in
Table 1.

In this study, Hydroxypropyl methylcellulose (HPMC) was developed in hot water with a ratio of $1: 20$ at a temperature of $70^{\circ} \mathrm{C}$ and left for about 30 minutes. The added propylene glycol, glycerin, and methylparaben had been dissolved in hot distilled water. It was crushed until it reached the homogeneous state, and the remaining water was added..$^{13}$ The EEA active ingredient with variations of 0 (F0), 1.5\% (F1), $2.5 \%$ (F2), and 3.5\% (F3) was added gradually into the gel base during the grinding process.

Moreover, before gel application, irritation skin was conducted on volunteer skin. The gel was applied to the forearm with a diameter of $\pm 3 \mathrm{~cm}$, and changes were observed in the form of redness, itching, and skin roughening for 24 hours. ${ }^{14} \mathrm{~A}$ skin analyzer measured the efficacy of anti-aging.

All data were analyzed using SPSS (Statistical Product and Service Solution) 21. The result of phytochemical screening was expressed as a qualitative scale. Moreover, antioxidant assay, total phenolic content, and total flavonoid content were expressed as $\mu \mathrm{g} / \mathrm{ml}, \mathrm{GAE} / \mathrm{g}$ extract, and $\mathrm{QE} / \mathrm{g}$ extract. Meanwhile, the parameter of anti-aging was expressed as a percentage (\%) and analyzed by the Kruskal Wallis test.

\section{Results}

Ethanol Extract of Asparagus (EEA) contained several phytochemicals as secondary metabolites and includes glycoside, steroid or triterpenoids, flavonoid, tannin, and saponin. On the other hand, the result of the antioxidants assay against the EEA as the sample and vitamin $C$ as the positive control using the DPPH method was expressed as $\mathrm{IC}_{50}(\mu \mathrm{g} / \mathrm{mL})$ and shown in Table 2 .

The $\mathrm{IC}_{50}$ of EEA was $118.992 \mu \mathrm{g} / \mathrm{mL}$, while vitamin $\mathrm{C}$ as the positive control had an $\mathrm{IC}_{50}$ of $2.693 \mu \mathrm{g} / \mathrm{mL}$. This indicated that the component

\section{Table 1 EEA Gel Formulation}

\begin{tabular}{ll}
\hline Material & Concentration (\%) \\
\hline HPMC & $1 \%$ \\
Propylene glycol & $10 \%$ \\
Glycerin & $5 \%$ \\
Nipagin & $0.1 \%$ \\
Triethanolamine & Quantum sufficit \\
Distilled Water & $100 \%$ \\
\hline
\end{tabular}


HS Ginting et al: Anti-Aging Activities of Asparagus Gel Ethanol Extract in Cosmetic Gel Agent for Facial Skin

Table 2 Antioxidant Assay Results

\begin{tabular}{lccc}
\hline & Group & Regression Equation & $\mathbf{I C}_{\mathbf{5 0}}(\boldsymbol{\mu g} / \mathbf{m L})$ \\
\hline EEA & $\mathrm{y}=0.3507 \mathrm{x}+8.260$ & 118.992 \\
Vitamin C & $\mathrm{y}=17.548 \mathrm{x}+2.7315$ & 2.6935 \\
\hline
\end{tabular}

Table 3 Total Phenolic and Total Flavonoid Content of EEA

\begin{tabular}{lccccc}
\hline Phytochemical & $\begin{array}{c}\text { Concentration } \\
\text { (ppm) }\end{array}$ & $\begin{array}{c}\text { Volume } \\
\text { (L) }\end{array}$ & $\begin{array}{c}\text { Dilution } \\
\text { Factor }\end{array}$ & $\begin{array}{c}\text { Mass of } \\
\text { Sample (g) }\end{array}$ & Content \\
\hline Total Phenolics & 16,0683 & 0.025 & 1 & 0.0252 & $15,9407 \mathrm{GAE} / \mathrm{g}$ extract \\
Total Flavonoid & 3,2545 & 0.025 & 1 & 0.0252 & 3,2286 QE/g extract \\
\hline
\end{tabular}

in EEA had a moderate antioxidant activity (100$150 \mu \mathrm{g} / \mathrm{mL}$ ), which was in contrast with vitamin $\mathrm{C}$ that had a very strong antioxidant activity (less than $50 \mu \mathrm{g} / \mathrm{mL})^{9}{ }^{9}$

The EEA was also treated to determine its total phenolic and flavonoid contents. These were expressed as Gallic Acid Equivalent (GEA) and Quercetin Equivalent (QE) for each gram of extract. The total phenolic and flavonoid contents of the EEA were shown in Table 3.

The next process involved the formulation of the EEA into a gel form for the clinical trial. The irritation test showed no sign of a reaction, such as redness, itching, and skin roughness among volunteers. Therefore, the EEA gel preparations are safe to be used. Hence, all volunteers were asked to apply the gel for 4 weeks, and the results of the parameter analysis was shown in Table 4, and the percentage of recovery after using the AAE gel was shown in Figure.

The percentage of recovery for all parameters was shown to have a similar pattern. The FIII formulation was shown to have the highest percentage of recovery for moisture (40.1\%), oil content $(49.7 \%)$, texture $(71.7 \%)$, collagen $(17.70 \%)$, wrinkles $(70.93 \%)$, spots $(49.3 \%)$, sensitivity (42.6\%), and pore $(25.3 \%)$ than other formulations. In contrast, the lowest percentage of recovery was demonstrated by F0.

\section{Table 4 EEA Gel Effectiveness}

\begin{tabular}{|c|c|c|c|c|c|c|}
\hline \multirow{2}{*}{ Parameter } & \multirow{2}{*}{$\begin{array}{l}\text { Testing } \\
\text { Time }\end{array}$} & \multicolumn{5}{|c|}{ Treatment (Mean \pm SD) } \\
\hline & & F0 & F1 & F2 & F3 & $\mathbf{P}$ \\
\hline \multirow{2}{*}{ Moisture } & Before & $74.67 \pm 2.08$ & $76.67 \pm 2.08$ & $63.33 \pm 4.16$ & $43.00 \pm 9.85$ & 0.021 \\
\hline & After & $89.67 \pm 1.52$ & $98.00 \pm 0.00$ & $92.00 \pm 3.46$ & $72.33 \pm 18.71$ & 0.021 \\
\hline \multirow{2}{*}{ Oil Content } & Before & $59.67 \pm 2.88$ & $62.00 \pm 3.46$ & $63.00 \pm 2.64$ & $73.00 \pm 8.72$ & 0.148 \\
\hline & After & $46.33 \pm 3.51$ & $43.00 \pm 3.61$ & $39.67 \pm 1.52$ & $36.67 \pm 4.04$ & 0.044 \\
\hline \multirow[t]{2}{*}{ Texture } & Before & $9.33 \pm 1.53$ & $8.67 \pm 1.53$ & $10.00 \pm 0.00$ & $8.33 \pm 0.57$ & 0.255 \\
\hline & After & $4.33 \pm 0.57$ & $3.67 \pm 0.57$ & $4.00 \pm 1.00$ & $2.33 \pm 0.57$ & 0.083 \\
\hline \multirow{2}{*}{ Collagen } & Before & $86.67 \pm 2.31$ & $83.67 \pm 1.53$ & $81.33 \pm 1.15$ & $79.00 \pm 0.00$ & 0.022 \\
\hline & After & $94.67 \pm 0.21$ & $97.33 \pm 1.15$ & $97.67 \pm 0.57$ & $96.00 \pm 1.00$ & 0.087 \\
\hline \multirow{2}{*}{ Wrinkle } & Before & $8.00 \pm 1.00$ & $8.00 \pm 1.00$ & $8.67 \pm 1.52$ & $9.00 \pm 1.00$ & 0.597 \\
\hline & After & $5.00 \pm 1.00$ & $3.67 \pm 0.57$ & $3.67 \pm 0.57$ & $2.67 \pm 1.15$ & 0.111 \\
\hline \multirow{2}{*}{ Spot } & Before & $26.33 \pm 0.57$ & $24.33 \pm 1.52$ & $27.00 \pm 0.00$ & $31.33 \pm 4.16$ & 0.020 \\
\hline & After & $21.33 \pm 0.57$ & $16.33 \pm 1.52$ & $15.00 \pm 0.00$ & $16.00 \pm 3.60$ & 0.059 \\
\hline \multirow{2}{*}{ Sensitivity } & Before & $20.67 \pm 1.15$ & $22.67 \pm 2.51$ & $23.33 \pm 2.08$ & $24.33 \pm 0.57$ & 0.188 \\
\hline & After & $15.67 \pm 1.15$ & $15.33 \pm 1.52$ & $14.33 \pm 1.15$ & $14.00 \pm 1.73$ & 0.483 \\
\hline \multirow{2}{*}{ Pore } & Before & $1.00 \pm 0.00$ & $1.00 \pm 0.00$ & $1.00 \pm 0.00$ & $72.67 \pm 16.56$ & 0.013 \\
\hline & After & $1.00 \pm 0.00$ & $1.00 \pm 0.00$ & $1.00 \pm 0.00$ & $54 \pm 10.53$ & 0.013 \\
\hline
\end{tabular}




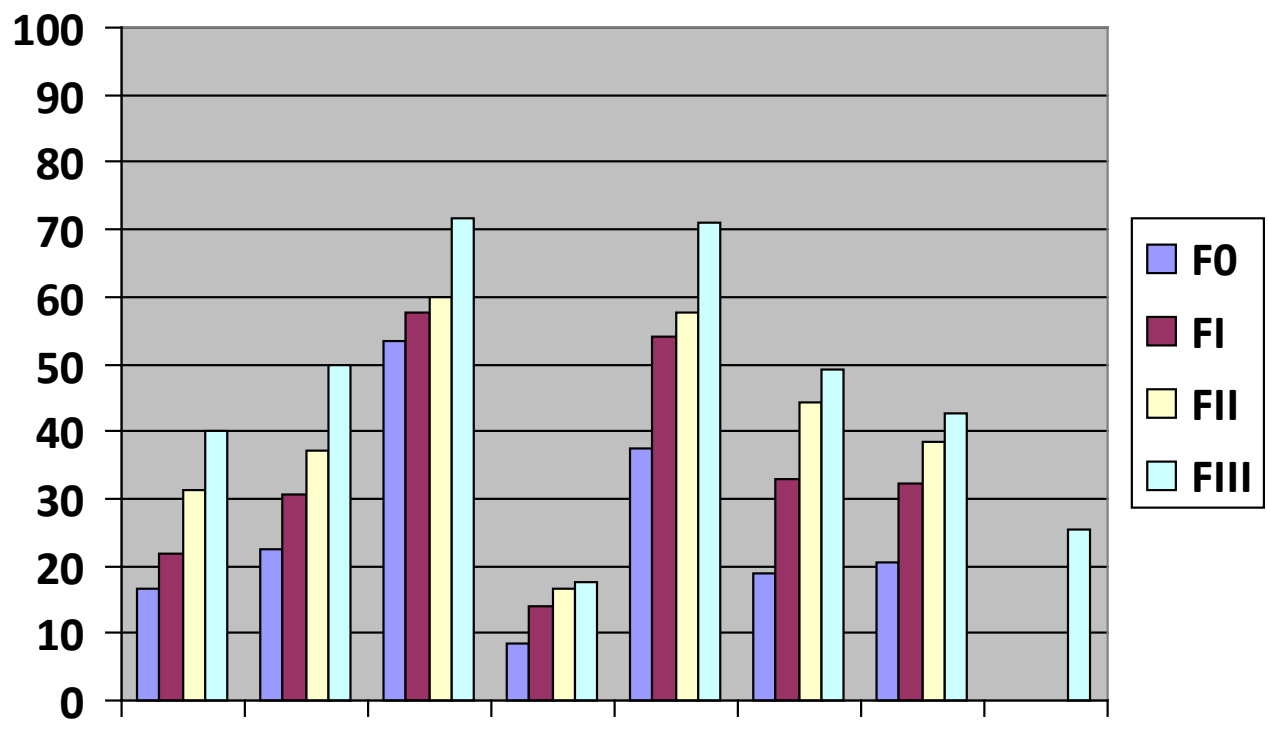

Figure Percentage of Facial Skin Recovery After Using Asparagus Ethanol Extract Gel

\section{Discussion}

The result of this study indicates the presence of various pharmacological properties that not only increase the skin moisture and collagen content but also reduce the oil content, texture, wrinkles, spot, sensitivity, and pore. These pharmacological properties were due to the fact that Ethanol Extract of Asparagus (EEA) has a moderate antioxidant activity by scavenging DPPH. The EEA antioxidant activity is due to the total phenolic and flavonoid contents of 15,9407 $\mathrm{GAE} / \mathrm{g}$ extracts and 3,2286 QE/g extracts, respectively. Therefore, this in vitro study shows potential anti-aging properties of EEA. Moreover, the EEA was evaluated as gel preparation in three different formulations (F1, F2, and F3), and all formulations demonstrate an improvement in the facial skin parameters after 4 weeks ( $p$-value $<0.05$ ).

The gel penetration through the skin occur via percutaneous absorption that enable the gel to enter the bloodstream. In contrast, the penetration of drugs through the skin occur via the transdermal (stratum corneum) and transfollicular (sweat and sebum gland pores) routes. Propylene glycol is an enhancer that interacts with stratum corneum lipids and water to increase hydration in the skin tissue which increases the delivery of hydrophilic and lipophilic drugs, influencing drug solubility in the stratum corneum and affecting the carrier partition into the membrane. The increase in penetration in gel preparations also accelerates the effectiveness of medicinal ingredients ${ }^{15}$.

The antioxidant compounds in asparagus were flavonoids and tannins, with a moderate antioxidant activity as indicated by the $\mathrm{IC}_{50}$ value of ethanol extract by $118.992 \mu \mathrm{g} / \mathrm{mL}$, which was supported by the phenol and flavonoid contents. Phenolic compounds are a source of natural antioxidants. Phenol and flavonoid compounds have a linear contribution to antioxidant activity. Therefore, the higher the levels are, the better the antioxidants. ${ }^{16}$ Before applying the gel, the patient's skin condition was dry epidermisdermis, oily, perfect texture, sufficient collagen fiber, no wrinkles, spots, sensitive, and no serious pores. After 4 weeks of gel application, there was an improvement in skin condition, resulting in moist, oily balance, perfect texture, sufficient collagen fiber with no wrinkles, normal spots, normal facial skin sensitivity, and decreased pore size. Asparagus keeps the facial skin moist by maintaining sebum production in the stratum corneum and removes fat in oily skin., ${ }^{2,17}$ The use of $3.5 \%$ asparagus ethanol extract gel (FIII) is shown to lead to the best effect in all parameters (Figure).

Antioxidants and flavonoids work to 
stimulate the formation and production of skin collagen, preventing collagen degradation. In addition, it maintains and improves facial skin texture by preventing the increase in ROS in the dermis layer, thereby inhibiting the formation of AP-1 and the MMP enzyme. Increased collagen maintains skin elasticity, flexibility, and smoothness. ${ }^{18}$ The asparagus that is formulated into a gel preparation is based on Hydroxypropyl methylcellulose, which is a cellulose derivative increases the stimulation of growth factors, such as the Epidermal Growth Factor (EGF), Fibroblast Growth Factor (FGF), and Plateletderived Growth Factor (PDGF). Growth factors play an important role in regulating normal growth and development by stimulating cell division; maintaining the tissue repair phase; accelerating skin regeneration; and stimulating collagen formation. ${ }^{16,19}$ Furthermore, flavonoids from the EEA inhibit the pigmentation process or the appearance of spots by directly inhibiting the tyrosinase activity in the melanogenesis process. Antioxidants can keep facial skin from overreacting, which will interfere with skin health, and prevents irritation and allergies.Enlarged pores may also be reduced by regular exfoliation and collagen formation, which will improve the skin condition..$^{20}$ Hence, it can be concluded that Asparagus have a moderate antioxidant activity by scavenging DPPH contributed by the presence of phenolic and flavonoid. Moreover, the highest concentration of EEA Gel (3.5\%) shown the highest percentage of skin moisture, oil content, texture, collagen, wrinkles, spots, sensitivity, and pore, which promotes an anti-aging activity.

\section{References}

1. Sumantri IB, Wahyuni HS, Mustanti LF. Total phenolic, total flavonoid and phytochemical screening by FTIR spectroscopic of standardized extract of Mikania micrantha leaf. Pharmacogn J. 2020;12(6):1395-401.

2. Putra B, Waluyo S. The Book Of Anti Aging Rahasia Awet Muda Mind, Body, Spirit. PT Elex Media Komputindo; 2010.

3. Mondal SC, Singh P, Kumar B, Singh SK, Gupta SK, Verma A. Ageing and potential anti-aging phytochemicals: an overview. World J Pharm Pharm Sci. 2015;4(1):426-54.

4. Singh DB, Ahmed N, Singh SR, Mir KA, Lal S. Variation in chlorophyll and carotenoid contents in kale (Brassica oleracea) as influenced by cultivars and harvesting dates. Indian J Agric Sci. 2014;84(10):1178-81.
5. Ardhie A. Radikal bebas dan peran antioksidan dalam mencegah penuaan. Medicinus Anti Aging. Sci J Pharm Dev Med Appl. 2011;24(1):4-9.

6. Styawan W, Linda R, Mukarlina. Pemanfaatan tumbuhan sebagai bahan kosmetik oleh suku melayu di Kecamatan Sungai Pinyuh Kabupaten Mempawah. J Protobiont. 2016;5(2):45-52.

7. Rathod HJ, Mehta DP. A Review on Pharmaceutical Gel. Int J Pharm Sci. 2015;1(1):33-47.

8. Ginting E, Utomo JS, Yulifianti R. Potensi ubi jalar ungu sebagai pangan fungsional. Iptek Tanam Pangan. 2015;6(1):116-38.

9. Mutia MS, Chiuman L. Hepatoprotective effect of citrus sinensis (L.) osbeck ethanol extract in paracetamol-induced rats efek hepatoprotektif ekstrak etanol citrus sinensis l. osbeck pada tikus yang diinduksi parasetamol. MKB. 2019;51(4):189-93.

10. Widowati W, Ratnawati H, Retnaningsih C, Lindayani, Rusdi UD, Winarno W. Free radical scavenging and $\alpha$-glucosidase inhibitor activity of ethanolic extract of mucuna pruriens L. JFI. 2011;5(3):117-24.

11. Juanda D, Budiana W, Ridwan IM. Penetapan kadar total fenol dan aktivitas antioksidan dari jus buah lima spesies jeruk. Jurnal Farmasi Galenika. 2015;2(1):36-42.

12. Azizah DN, Kumolowati E, Faramayuda F. Penetapan kadar flavonoid metode $\mathrm{AlCl} 3$ pada ekstrak metanol kulit buah kakao (Theobroma cacao L.). Kartika J Ilm Farm. 2014;2(2):45-9.

13. Ardana M, Aeyni V, Ibrahim A. Formulasi dan optimasi basis gel HPMC (Hidroxy Propyl Methyl Cellulose) dengan berbagai variasi konsentrasi. J Trop Pharm Chem. 2015;3(2):101-8.

14. Khan HMS, Akhtar N, Rasool F, Khan BA, Mahmood T, Khan MS. In vivo evaluation of stable cream containing flavonoids on hydration and TEWL of human skin. World Academy Science Engineering Technology. 2010;47:896-9.

15. Zalukhu ML, Phyma AR, Pinzon RT. Proses menua, stres oksidatif, dan peran antioksidan. Cermin Dunia Kedokt. 2016;43(10):733-6.

16. Roya K, Fatemeh G. Screening of total phenol and flavonoid content, antioxidant and antibacterial activities of the methanolic extracts of three Silene species from Iran. Intl J Agri Crop Sci. 2013;5(3):305-12.

17. NSS Ambarwati, T Supiani, L Jubaedah. Pengaruh masker nanas untuk untuk 
mengurangi kadar minyak pada kulit wajah berminyak. Jurnal Tata Rias. 2012;1(1).

18. Choi DS, Kim S, Lim YM, Gwon HJ, Park JS, Nho YC, et al. Hydrogel incorporated with chestnut honey accelerates wound healing and promotes early $\mathrm{HO}-1$ protein expression in diabetic $(\mathrm{db} / \mathrm{db})$ mice. Tissue Eng Regen Med. 2012;9(1):36-42.
19. Charissa M, Joshita D, Elya B. Uji Aktivitas antioksidan dan penghambatan tirosinase serta uji manfaat gel ekstrak kulit batang taya (Nauclea subdita) terhadap Kulit. J Kefarmasian Indones. 2017;6(2):98-107.

20. Noormindhawati L. Jurus ampuh melawan penuaan dini. Jakarta: Elex Media Komputindo; 2013. 